\title{
Efficacy of Extracorporeal Shock Wave Therapy on Male Coccydenia after Urological Surgery
}

\author{
ASHRAF H. MOHAMED, Ph.D.; HEBA M. MOHAMEDY, Ph.D. and MOHAMED R. MOHAMED, M.Sc. \\ The Department of Physical Therapy for Surgery, Faculty of Physical Therapy, Cairo University
}

\begin{abstract}
Background: UROLOGIC pelvic surgery is the integration of surgical activities for the pelvis, the colon, urogenital, and gynecological organs primarily for the treatment of obstructions, dysfunction, malignancies, and inflammatory diseases.

Aim of Study: To evaluate the efficacy of extracorporeal shock wave therpy on male coccydenia after urological surgery.

Subjects: Thirty male patients who complain from coccydenia after urological surgery, their age range from 40-60 years old, choosen from El-Sahel Teaching Hospital and Police Hospital in Agoza, Cairo, Egypt during the period of June-2017 to November-2017.

Methods: Patients assigned randomly into two groups of equal numbers, Group (A) control group which include 15 patients received routine medication only (anti-inflammatory drugs or NSAID), and Group (B) study group received shock wave therapy one session per week up to four weeks each session took 10 minutes the patients were received 2000 shots of ESWT in the coccyx, the frequency was $5 \mathrm{~Hz}$ and the pressure was 3-4 bar in addition to traditional medications routine (anti-inflammatory drugs). Both groups were assessed pre and post-treatment for pain level by Visual Analogue Scale (VAS).

Results: There was a significant decrease in the median values of visual analogue scale post-treatment of study group compared with control group $(p=0.002)$ in favor of study group.

Conclusion: Shock wave therapy is effective as a physical therapy program on improving coccydenia.
\end{abstract}

Key Words: Shock wave therapy - Male coccydenia - Urological surgery.

\section{Introduction}

UROLOGIC pelvic surgery is the integration of surgical activities for the pelvis, the colon, urogenital, and gynecological organs primarily for the

Correspondence to: Dr. Ashraf H. Mohamed, The Department of Physical Therapy for Surgery, Faculty of Physical Therapy, Cairo University treatment of obstructions, dysfunction, malignancies, and inflammatory diseases. Common urologic operations include urethra surgery, prostatic surgery, removal of the prostate, pelvic lymph node dissection, surgery of the ureters, including ureterolithotomy or removal of calculus (stones) in the ureters and testicular (scrotal) surgery [1]

Conditions that commonly dictate a need for urologic surgery include neurogenic sources like spinal cord injury; injuries to the pelvic organs; chronic digestive and urinary diseases; as well as prostate infections and inflammations. There are many other common chronic and malignant diseases that can benefit from resection, surgical augmentation, or surgery to clear obstructions. These conditions impact the digestive, renal, and reproductive systems [2].

The risks of urologic surgery vary with the type of surgical procedure (open or laparacopic), and the extent of organ involvement. According to one study of 2,407 urologic surgeries in four centers, the overall complication rate was $4.4 \%$, with a mortality rate of $0.08 \%$ [3] .

Coccydynia is pain around the coccygeal region that may be caused by sudden impact over the coccyx area from falls or traumatic injuries, resulting in pain and inflammatory changes of the surrounding ligaments and muscles [4]. Pain in these conditions is associated with coccygeal instability or subluxation, and patients develop subsequent coccydynia [5]

Patients with coccydynia often complain of pain and local tenderness around the coccyx [6] Surgical interventions with the excision of the mobile coccyx or a total coccygectomy relieve approximately $80 \%$ to $90 \%$ of symptoms [7]. 
The term "shock wave" denotes a high-energy sound wave that terminates in a bursting of energy similar to a mini-explosion. It is essentially the same as a super-sonic jet breaking the sound barrier and creating an energy force strong enough to shatter windows. ESWT utilizes a high peak pressure ranging from 5 to $130 \mathrm{Mpa}$, with a physical properties of the extracorporeal shock wave. Of this unique form of energy is the rapid initial rise in pressure amplitude (500 bar) over a short life cycle of less than 10ns [8]

Since 2010 shockwaves have been used in urology, to treat chronic pelvic pain syndrome and erectile dysfunction. Unlike drugs ESWT is noninvasive, without side effects and promotes long term healing. There are a growing number of double blind sham controlled double blind studies that show success rates of up to $80 \%$ [9]

However, the effects of ESWT on low back pain and coccydynia are less discussed till now. It was reported that exercise program combined with ESWT relieved chronic low back pain and improved dynamic balance more than exercise program with conservative physical therapy [10]

It is believed that shock wave therapy alleviates pain by the induction of neovascularisation and improvement of blood supply to the tissue and by initiating repairs to the chronically inflamed tissues by tissue regeneration [11]

The experimental findings confirm that ESWT decreases the expression of high levels of inflammatory mediators (matrix metalloproteinases and interleukins). Therefore, ESWT produces a regenerative and tissue-repairing effect in musculoskeletal tissues, not merely a mechanical disintegrative effect, as was previously generally assumed [12]

\section{Subjects and Methods}

This study was carried out at El-Sahel Teaching Hospital and Police Hospital in Agoza, Cairo, Egypt and during the period between June-2017 to November-2017.

Subjects: Thirty patients who complains from coccydenia after urological surgery. They were selected from El-Sahel Teaching Hospital and Police Hospital in Agoza, Cairo, Egypt and patients were assigned randomly into two groups of equal numbers, (group A and group B).

\section{Inclusive criteria:}

All patients were suffered from coccydenia after urological surgery, were males and their age 40-60 years, conscious, well-nourished and co- operative free from other neurological problems, free from any previous surgeries.

\section{Exclusion criteria:}

Uncooperative patients, instability of patient's medical condition, association of other medical problems, presence of any disease that could affect the research results such as renal diseases.

Equipment: The study equipment were divided into two different categories, measuring and therapeutic equipment.

- Measurment equipment: Evaluation by Visual Analogue Scale (VAS).

- Treatment equipment: Shock wave therapy with high peak pressure, sometimes more than 100 MPa (500 bar) within less than 10ns (nanoseconds), followed with a low tensile amplitude (up to $10 \mathrm{MPa}$ ), a short life cycle of approximately $\mathrm{n} 10$ and a broad frequency spectrum in the range of 16 to $20 \mathrm{MHz}$.

Procedure of application: The subjects will be informed about the nature of the study; each subject signed consent form before participating in the study. Treatment time of the present study was given in the period of 12 weeks.

- Group A (shock wave therapy group): In this group of the study, fifteen patients were received shock wave therapy one session a week for 4 consecutive weeks each session took 10 minutes the patients were received 2000 shots of ESWT in the coccyx, the frequency was $5 \mathrm{~Hz}$ and the pressure was 3-4 bar.

- Group B (control group): In this group, fifteen patients were received routine medications only.

Ethical consideration: Confidentiality was assured by signing the consent form and respect to all patients was ascertained through explaining the objectives, procedures of the study and its benefits. The study was approved by Ethical Committee of Faculty of Physical Therapy, Cairo University. (P.T.REC/012/001000).

\section{Results}

Comparing the median values of Visual Analog Scale (VAS) between the two groups (A and B) before treatment, the median values were 8 and 7 respectively with a none significant difference ( $p=$ 0.165 ), while comparing the two groups after four weeks of treatment, the median values were 3 and 4 respectively which indicated a significant difference $(p=0.002)$ in favor of group A $(\mathrm{MD}=1)$ and $\%$ of improvement was $18.33 \%$. 
Table (1): Comparing the pre and post-treatment median values of Visual Analogue Scale (VAS) for each group.

\begin{tabular}{|c|c|c|c|c|}
\hline \multirow{2}{*}{$\begin{array}{l}\text { Visual Analog } \\
\text { Scale (VAS) }\end{array}$} & \multicolumn{2}{|c|}{ Group (A) } & \multicolumn{2}{|c|}{ Group (B) } \\
\hline & $\begin{array}{c}\text { Pre- } \\
\text { treatment }\end{array}$ & $\begin{array}{c}\text { Post- } \\
\text { treatment }\end{array}$ & $\begin{array}{c}\text { Pre- } \\
\text { treatment }\end{array}$ & $\begin{array}{c}\text { Post- } \\
\text { treatment }\end{array}$ \\
\hline Median & 8 & 3 & 7 & 4 \\
\hline MD & \multicolumn{2}{|l|}{5} & \multicolumn{2}{|l|}{3} \\
\hline$\%$ of improvement & \multicolumn{2}{|c|}{$31.58 \%$} & \multicolumn{2}{|c|}{$32.78 \%$} \\
\hline z-value & \multicolumn{2}{|c|}{27.88} & \multicolumn{2}{|c|}{10.46} \\
\hline$p$-value & \multicolumn{2}{|c|}{0.000} & \multicolumn{2}{|c|}{0.000} \\
\hline Level of significant & \multicolumn{2}{|l|}{ S } & \multicolumn{2}{|l|}{ S } \\
\hline
\end{tabular}

\begin{tabular}{ll}
\hline Pre & : Before application of treatment. \\
Post & : After four weeks of treatment. \\
SD & $:$ Standard Deviation. \\
MD & : Mean Difference. \\
\% of improvement : Percentage of improvement. \\
Z-value : Wilcoxon Signed Ranks test. \\
$p$-value & : Probability value. \\
S & $:$ Significant.
\end{tabular}

Table (2): Comparing between pre and post-treatment median values of Visual Analog Scale (VAS) between the two groups.

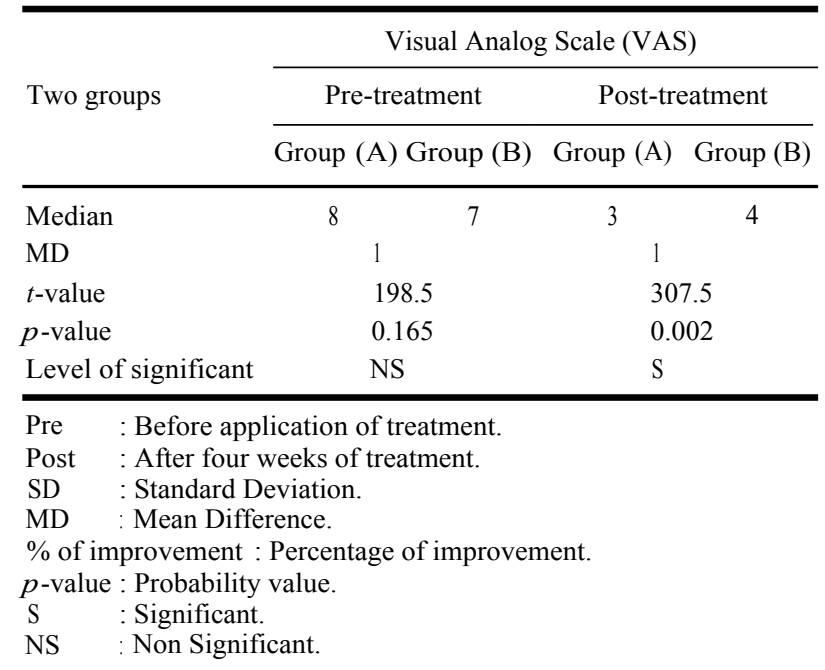

\section{Discussion}

The current study was designed to evaluate the effect of shock wave therapy on coccydenia, which refers to pain in the region of the coccyx. This condition can lead to chronic pain and functional impairment, limiting the quality of life of the patients. Patients usually complain of pain while sitting, which worsens when rising from a seated position and leaning back while seated [13].

Some patients also experience coccygeal pain with sexual intercourse or defecation, and females can have exacerbation during vaginal delivery or during the premenstrual period. Coccydynia is a result of multiple factors. Trauma, in the form of direct fall, difficult vaginal delivery or repetitive minor injury due to sitting on hard objects, is by far the most common cause of coccygeal pain [14] In addition, abnormal mobility of the coccyx and various morphologic features were found to be associated with coccydynia [15]

In recent years, Extracorporeal Shock Wave Therapy (ESWT) has been suggested for noninvasive treatment of many musculoskeletal conditions, including plantar fasciitis [16], epicondylitis and shoulder calcification [17]

\section{Conclusion:}

From the previous results and discussions, it could be concluded that shock wave therapy is effective as a physical therapy program on improving coccydenia. This study maybe useful for reducing and improving symptoms of coccydenia and physical performance of daily living activities, because of independent lifestyle among those population.

\section{References}

1- PAVLOVICH C.P., TROCK B.J., SULMAN A., WAGNER A.A., METTEE L.Z. and SU L.M.: " 3-year actuarial biochemical recurrence-free survival following laparoscopic radical prostatectomy: Experience from a tertiary referral center in the United States". J. Urol., 179: $917-$ 21, 2008.

2- CLARK P.E., STEIN J.P. and GROSHEN S.G.: "Radical cystectomy in the elderly: Comparison of clinical outcomes between younger and older patients". Cancer, 104: (1): 36-43, 2005.

3- McDOUGAL W.S.: "Cancer of the bladder, ureter, and renal pelvis. Philadelphia: Lippincott Williams and Wilkins"; 1: 1358-84, 2008.

4- PATEL R., APPANAGARI A. and WHANG P.G.: "Coccydynia. Curr. Rev. Musculoskelet. Med.", 1: 223-6, 2008.

5- MAIGNE J.Y., DOURSOUNIAN L. and CHATELLIER G.:" Causes and mechanisms of common coccydynia: Role of body mass index and coccygeal trauma". Spine, 25: 3072-9, 2008.

6- BALAIN B., EISENSTEIN S.M., ALO G.O., DARBY A.J., CASSAR-PULLICINO V.N. and ROBERTS S.E.:" Coccygectomy for coccydynia: Case series and review of literature". Spine, 31; E414-20, 2006.

7- TOTH-KISCHKAT A.: "Physical principles of shockwave". Presented at the 3 rd Congress of the International Society of Musculoskeletal Shockwave Therapy, 41: 3, 2000.

8- VAHDATPOUR B., ALIZADEH F., MOAYEDNIA A., EMADI M., KHORAMI M.H. and HAGHDANI S. "Efficacy of extracorporeal shock wave therapy for the treatment of chronic pelvic pain syndrome: A randomized, controlled trial”. ISRN Urology, 972601, 2013.

9- LEE S., LEE D. and PARK J.: "Effects of extracorporeal shockwave therapy on patients with chronic low back pain and their dynamic balance ability". J. Phys. Ther. Sci., 26: 7-10, 2014. 
10- WANG C.J., KO J.Y., CHAN Y.S., WENG L.H. and HSU S.L.: "Extracorporeal shockwave for chronic patellar tendinopathy". The American Journal of Sports Medicine, 35: (6): 972-8, 2007.

11- NOTARNICOLA A. and MORETTI B.: "The biological effects of extracorporealshock wave therapy (eswt) on tendon tissue". Muscles Ligaments Tendons J., 2 (1): 337,2012 .

12-NATHAN S.T., FISHER B.E. and ROBERTS C.S.: "Coccydynia: A review of pathoanatomy, aetiology, treatment and outcome". J. Bone Joint Surg. Br., 92: 1622-7, 2010.

13- MAIGNE J.Y. and CHATELLIER G.: "Comparison of three manual coccydynia treatments: A pilot study". Spine; 26: E479-483; discussion E484, 2001.
14- DOURSOUNIAN L., MAIGNE J.Y. and JACQUOT F.: "Coccygectomy for coccygeal spicule: A study of 33 cases". Eur. Spine J., 2015 Jan. 6, 2015.

15- DIZON J.N., GONZALEZ-SUAREZ C., ZAMORA M.T. and GAMBITO E.D.:" Effectiveness of extracorporeal shock wave therapy in chronic plantar fasciitis: A metaanalysis. Am. J. Phys. Med. Rehabil.", 92: 606-20, 2013.

16- CHILDRESS M.A. and BEUTLER A.: "Management of chronic tendon injuries". Am. Fam. Physician., 87: 48690, 2013.

17- PETERS J., LUBOLDT W., SCHWARZ W., JACOBI V., HERZOG C. and VOGL T.J.: "Extracorporeal shock waveVE therapyin calcific tendinitis of the shoulder". Skeletal. Radiol., 33: 712-8, 2004.

\section{تآثير الموجات الخارجية التصادمية على الآلم العصعصى الهصى بعد جراحات المسالك البولية}

الهدف من هذا البحث: يهدف هذا البحث إلى دراسة تآثير الموجات الخارجية التصادمية على مرضى الآلم العصعصى بعد جراحات

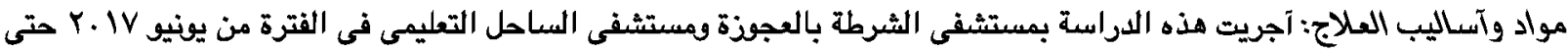

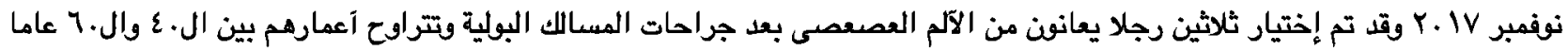

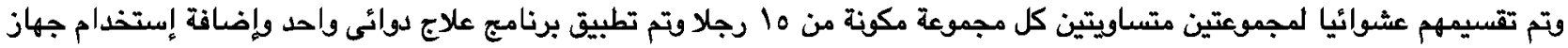

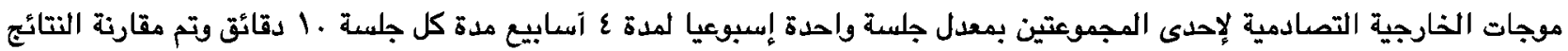
العلاجية للمجموعتين عن طريق إستخدام مقياس الآلم البصرى قبل وبعد البرنامج العلاجى المجموعية جئين. وقَ آظهرت النتائج ما يلخى:

هى وجود فروق ذات دلالة إحصائية كبيرة بين مجموعة البحث والمجموعة التى خضعت اللعلاج الدوائى فقط قهى: وجود إنخفاض ملحوظ في القيم الوسيطة لمقياس الآلم البصرى لصالح مجهوعة الدراسة بالمقارنة بالمجموعة الآخرى وكانت نسبة التحسن

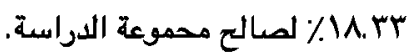

ومن هنا يمكن الإستنتاج أن تطبيق العلاج من خلال إستخدام العلاج الدوائى مع جهاز الموجات الخارجية التصادمية له التآثير الآفضل

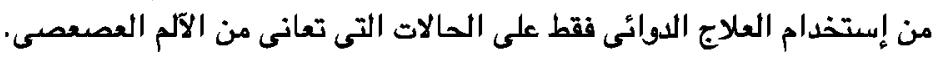

